\title{
Snail Survey in Water Canals for Detecting Their Infection with Parasitic
} Trematodes in Al-Fayoum Governorate,Egypt

\author{
Abd El-Hafeez \\ IA $^{(1)}$, Sabry $\mathrm{AA}^{(1)}$, Eldardiry MA $^{(1)}$, El-Emam MA ${ }^{(2)}$ \\ and Youseef $\mathbf{A A}^{(2)}$ \\ (1) Medical Parasitology Department, Faculty of Medicine,Fayoum \\ University. \\ (2) Medical Malacology Department, Theodor Bilharz \\ Research Institute.
}

Corresponding author: Islam Ahmed Abd El-Hafeez AliEmail address: eaa09@fayoum.edu.eg

Tel: 01060398684

\begin{abstract}
Freshwater snails have significant consideration as they may act as intermediate hosts of several parasitic infections, mainly trematodes that may cause serious diseases in humans and domestic animals. In Egypt, these are most notably schistosomiasis and fascioliasis. The aim of this study is to survey and examine fresh water snails in some water courses of rural districts at Al-Fayoum governorate for the presence of parasitic infective stages. Eight different watercourses were involved in this study. Snail sampling was conducted seasonally between spring 2018 to winter 2019 . Eleven Trematode species of fresh water snails were detected in the chosen watercourses, out of them only 5 speies were naturally infected with trematodes, (e.g. B.alexandrina with Schistosoma mansoni, B. trancatus with $S$.
\end{abstract} haematobium). Informationgained from such studies supposed to help in giving indication on the risk sites and times where the snail vectors of trematodes should be attacked.

KEY WORDS: Fresh-water snails, Trematode, Schistosomes, Parasites and Al-Fayoum governorate. 


\section{INTRODUCTION}

Freshwater snails have significant consideration as they may act as intermediate hosts of several parasitic infections, mainly trematodes that may cause serious diseases in humans and domestic animals [1]. Globally, 350 snail species are estimated to be of possible medical or veterinary importance. Most intermediate snail hosts of human Schistosoma parasites belong to three genera, Biomphalaria, Bulinus and Oncomelania. The species involved can be identified by the shape of the outer shell. Simple regional keys are available for the determination of most species. The snails can be divided into two main groups: aquatic snails that live under water and cannot usually survive elsewhere (Biomphalaria, Bulinus), and amphibious snails adapted for living in and out of water (Oncomelania). In Africa and the Americas, snails of the genus Biomphalaria serve as intermediate hosts of S.mansoni. Snails of the genus Bulinus serve as the intermediate hosts of $S$. haematobium in Africa and the Eastern Mediterranean, as well as of $S$. intercalatum in Africa. In south-east Asia, Oncomelania serves as the intermediate host of $S$. japonicum, and Tricula as the intermediate host of $S$. mekongi. Among the snail intermediate hosts of trematodes, the species belonging to the genus Lymnaea are of importance in the transmission of liver flukes. Lymnaea species may be either aquatic or amphibious [2].

In Egypt a survey carried out in AlFayoum governorate during Summer and Autumn of 2004, for snails of medical importance, nine species were recovered. These were Biomphalaria alexandrina, B. glabrata, $B$. pfeifferi, Bulinus truncatus, $B$. forskalii, Lymnaea natalensis, Bellamya unicolor, Physa acuta and Hydrobia musaensis. Parasitological examination revealed that $B$. alexandrina, $B$. glabrata and

L. natalensis harboured immature stages of their concerned trematode parasites. Moreover, $P$. acuta harboured the immature stage of the nematode parasite Parastrongylus cantonensis[3].

Therefore, this work evaluated the current distribution of certain snail species of medical impotance in water courses at Al-Fayoum governorate (2018-2019) and their role in transmission of human and veterinary trematode parasites (e.g. Schistosomiasis and fascioliasis).

\section{Materials and methods}

This study was conducted in AlFayoum Governorate. Eight different watercourses were involved (Senours, Bahr dissia, Hawaret el-maktaa, Bahr El- nazlah, Taton, Kasr El-geballi, Kasr Elbanat and Aboksah).They were selected on the basis of being next to agriculture areas and having obvious human water contact sites. Snail survey in these water courses was conducted seasonally from spring, 2018 to winter, 2019 using a standard dip net [4]. The physical and chemical parameters of water were measured directly in the selected watercourses.

The collected snails were transferred to Medical Malacology Laboratory, Theodor Bilharz Research Institute in ice box for sorting, identification and examination for their natural trematode infection [5].

\section{Result \\ The present data (Table 1) elicited that eleven species of fresh water snails were detected in the chosen watercourses: Biomphalaria alexandrina, Bulinus truncatus,}


Lymnaea natalensis, Melanoides tuberculata, Lanistes carinatus, Cleopatra bulimoides, Pila ovata, Theodoxus niloticus, Bellamya unicolor, Pseudosuccinea columella and Physa acuta. From the eleven species only 5 snails were naturally infected with trematodes;

Biomphalaria alexandrina, Bulinus truncatus, Melanoides tuberculata, Lanistes carinatus and Cleopatra bulimoides. Also,three species of trematodes cercariae were recorded; two of them were from $B$. alexandrina snails (Shistosoma mansoni and Echinostoma liei) and the third was from

B. truncatus (Schistosoma haematobium).

During spring, the water course Bahr dissia was characterized by the highest density of collected snail species (1961 snails) with 976 naturally infected number of snails collected from this watercourse $(49.77 \%$ infection rate, Table 2).

Regarding the summer season, the watercourses Bahr El-nazlah and Aboksah were found free from snails. Meanwhile, Hawaret el-maktaa was the highest infested with snail species (1668 snails) with $77.94 \%$ naturally infected snails out of the collected snails from this watercourse (Table 2).

For the autumn season, the watercourses Bahr El-nazlah and Aboksah were found free from snails but, Bahr dissia and Hawaret el-maktaa watercourses were characterized by approximately similar snail density (242 and 235 snails, respectively) with the highest infection rate in Hawaret el-maktaa ( $61.28 \%$ )of total number of collected snails from this

\begin{tabular}{|c|c|c|c|c|c|}
\hline $\begin{array}{l}\text { Lanistes carinatus } \\
\text { n } \\
\text { a }\end{array}$ & $\begin{array}{c}7 \\
(3)\end{array}$ & $\begin{array}{c}7 \\
(3)\end{array}$ & $\begin{array}{c}9 \\
(3)\end{array}$ & $\begin{array}{c}3 \\
(0)\end{array}$ & $\begin{array}{l}26 \\
(9)\end{array}$ \\
\hline $\begin{array}{l}\text { Gleopatra bulimoides } \\
1\end{array}$ & $\begin{array}{l}14 \\
(8)\end{array}$ & $\begin{array}{c}2 \\
(1)\end{array}$ & $\begin{array}{l}16 \\
(8)\end{array}$ & $\begin{array}{c}7 \\
(4)\end{array}$ & $\begin{array}{c}39 \\
(21)\end{array}$ \\
\hline $\begin{array}{l}\text { Pila ovate } \\
\mathrm{o}\end{array}$ & $\begin{array}{c}4 \\
(0)\end{array}$ & $\begin{array}{c}7 \\
(0)\end{array}$ & $\begin{array}{c}2 \\
(0)\end{array}$ & $\begin{array}{c}0 \\
(0)\end{array}$ & $\begin{array}{l}13 \\
(0)\end{array}$ \\
\hline 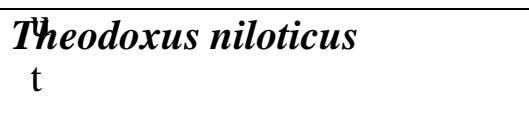 & $\begin{array}{l}10 \\
(0)\end{array}$ & $\begin{array}{c}6 \\
(0)\end{array}$ & $\begin{array}{c}9 \\
(0)\end{array}$ & $\begin{array}{c}7 \\
(0)\end{array}$ & $\begin{array}{l}32 \\
(\mathbf{0})\end{array}$ \\
\hline $\begin{array}{l}\text { Bellamya unicolor } \\
\mathrm{f}\end{array}$ & $\begin{array}{c}5 \\
(0)\end{array}$ & $\begin{array}{c}4 \\
(0)\end{array}$ & $\begin{array}{c}2 \\
(0)\end{array}$ & $\begin{array}{c}0 \\
(0)\end{array}$ & $\begin{array}{l}11 \\
(0)\end{array}$ \\
\hline$\underset{\mathrm{t}}{\text { Pseudosuccinea columella }_{\mathrm{h}}}$ & $\begin{array}{l}13 \\
(0)\end{array}$ & $\begin{array}{l}10 \\
(0)\end{array}$ & $\begin{array}{l}12 \\
(0)\end{array}$ & $\begin{array}{l}13 \\
(0)\end{array}$ & $\begin{array}{l}48 \\
(0)\end{array}$ \\
\hline $\begin{array}{l}\text { Physa acuta } \\
\mathrm{t}\end{array}$ & $\begin{array}{l}179 \\
(0)\end{array}$ & $\begin{array}{l}15 \\
(0)\end{array}$ & $\begin{array}{l}26 \\
(0)\end{array}$ & $\begin{array}{l}16 \\
(0)\end{array}$ & $\begin{array}{l}236 \\
(0)\end{array}$ \\
\hline $\begin{array}{l}\text { Total no. of Snails } \\
\mathrm{t}\end{array}$ & $\begin{array}{c}4808 \\
(1583)\end{array}$ & $\begin{array}{c}2831 \\
(1642)\end{array}$ & $\begin{array}{c}864 \\
(395)\end{array}$ & $\begin{array}{l}296 \\
(74)\end{array}$ & $\begin{array}{c}8799 \\
(3694)\end{array}$ \\
\hline $\begin{array}{c}\text { of of naturally infectedsnails } \\
1\end{array}$ & 32.92 & 58.04 & 45.72 & 25.00 & 41.98 \\
\hline
\end{tabular}


ISSN: 2536-9482 (Online) Fayoum University Medical Journal Abd El-Hafeez et al., 2018,8(3), 61-70

inter season, the watercourse Kasr ElGeballi was also found free fromsnails. However, Hawaret el-maktaa was infested on by with 99 snails and Bahr dissia exhibited $34.09 \%$ naturally infected snails out of the total number of collected snails from this watercourse (Table 2).

Table (1): Population density of collected and trematode infected snails from the examined watercourses during the four seasons (Spring, 2018 to Winter, 2019).

\begin{tabular}{|l|c|c|c|c|c|}
\hline & Spring & Summer & Autumn & Winter & Total \\
\hline Biomphalaria alexandrina & $\begin{array}{c}4432 \\
(1553)\end{array}$ & $\begin{array}{c}2696 \\
(1621)\end{array}$ & $\begin{array}{c}732 \\
(370)\end{array}$ & $\begin{array}{c}215 \\
(65)\end{array}$ & $\begin{array}{c}\mathbf{8 0 7 5} \\
(\mathbf{3 6 0 9})\end{array}$ \\
\hline Bulinus truncates & 68 & 50 & 28 & 13 & $\mathbf{1 5 9}$ \\
& $(11)$ & $(12)$ & $(8)$ & $(3)$ & $(\mathbf{3 4})$ \\
\hline Lymenae natalensis & 59 & 23 & 11 & 18 & $\mathbf{1 1 1}$ \\
& $(0)$ & $(0)$ & $(0)$ & $(0)$ & $(\mathbf{0})$ \\
\hline Melanoides tuberculata & 17 & 11 & 17 & 4 & $\mathbf{4 9}$ \\
& $(8)$ & $(5)$ & $(6)$ & $(2)$ & $(\mathbf{2 1})$ \\
\hline
\end{tabular}

*Number of infected snails is between brackets.

Table (2): Population density of collected and trematode infected snails in the examined watercourses during the four seasons (spring,2018 to winter,2019)

\begin{tabular}{|c|c|c|c|c|c|c|c|c|c|}
\hline & $\begin{array}{c}\text { Senou } \\
\text { rs }\end{array}$ & $\begin{array}{c}\text { Bahr } \\
\text { dissia }\end{array}$ & $\begin{array}{c}\text { Hawaret } \\
\text { el-maktaa }\end{array}$ & Taton & $\begin{array}{c}\text { Kasr } \\
\text { Elbanat }\end{array}$ & $\begin{array}{c}\text { Kasr El- } \\
\text { geballi }\end{array}$ & $\begin{array}{c}\text { Bahr El- } \\
\text { nazlah }\end{array}$ & Aboksah & Total \\
\hline Spring & 397 & 1961 & 727 & 541 & 373 & 327 & 250 & 232 & $\mathbf{4 8 0 8}$ \\
& $(11)$ & $(976)$ & $(201)$ & $(188)$ & $(43)$ & $(41)$ & $(98)$ & $(25)$ & $(\mathbf{1 5 8 3})$ \\
\hline Summer & 20 & 755 & 1668 & 240 & 75 & 73 & 0 & 0 & $\mathbf{2 8 3 1}$ \\
& $(4)$ & $(213)$ & $(1300)$ & $(85)$ & $(13)$ & $(27)$ & $(0)$ & $(0)$ & $(\mathbf{1 6 4 2})$ \\
\hline Autumn & 18 & 242 & 235 & 171 & 128 & 70 & 0 & 0 & $\mathbf{8 6 4}$ \\
& $(5)$ & $(101)$ & $(144)$ & $(88)$ & $(35)$ & $(22)$ & $(0)$ & $(0)$ & $\mathbf{( 3 9 5 )}$ \\
\hline Winter & 27 & 88 & 99 & 49 & 33 & 0 & 0 & 0 & $\mathbf{2 9 6}$ \\
\hline Total & $(9)$ & $(30)$ & $(19)$ & $(10)$ & $(6)$ & $(0)$ & $(0)$ & $(0)$ & $\mathbf{( 7 4 )}$ \\
\hline $\begin{array}{c}\text { \% of } \\
\text { naturally } \\
\text { infection }\end{array}$ & $\mathbf{4 6 2}$ & $\mathbf{3 0 4 6}$ & $\mathbf{2 7 2 9}$ & $\mathbf{1 0 0 1}$ & $\mathbf{6 0 9}$ & $\mathbf{4 7 0}$ & $\mathbf{2 5 0}$ & $\mathbf{2 3 2}$ & $\mathbf{8 7 9 9}$ \\
$\mathbf{( 1 3 2 0 )}$ & $\mathbf{( 1 6 6 4 )}$ & $\mathbf{( 3 7 1 )}$ & $\mathbf{( 9 7 )}$ & $\mathbf{( 9 0 )}$ & $\mathbf{( 9 8 )}$ & $(\mathbf{2 5})$ & $\mathbf{( 3 6 9 4 )}$ \\
\hline
\end{tabular}

\footnotetext{
*Number of infected snails is between brackets.
} 
ISSN: 2536-9482 (Online) Fayoum University Medical Journal Abd El-Hafeez et al., 2018,8(3), 61-70

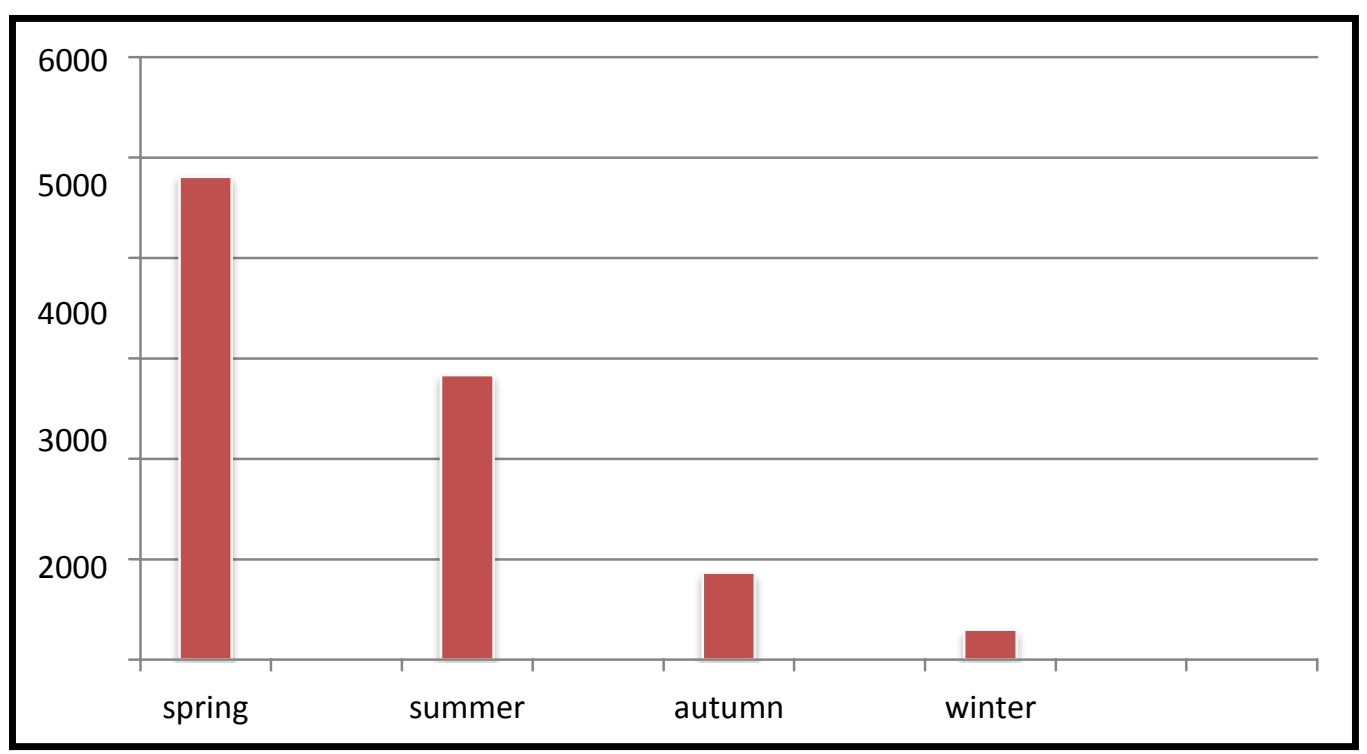

Fig (1): Population density of snails in the examined watercourses during the four seasons (spring,2018 to winter,2019) at Al-Fayoum Governorate

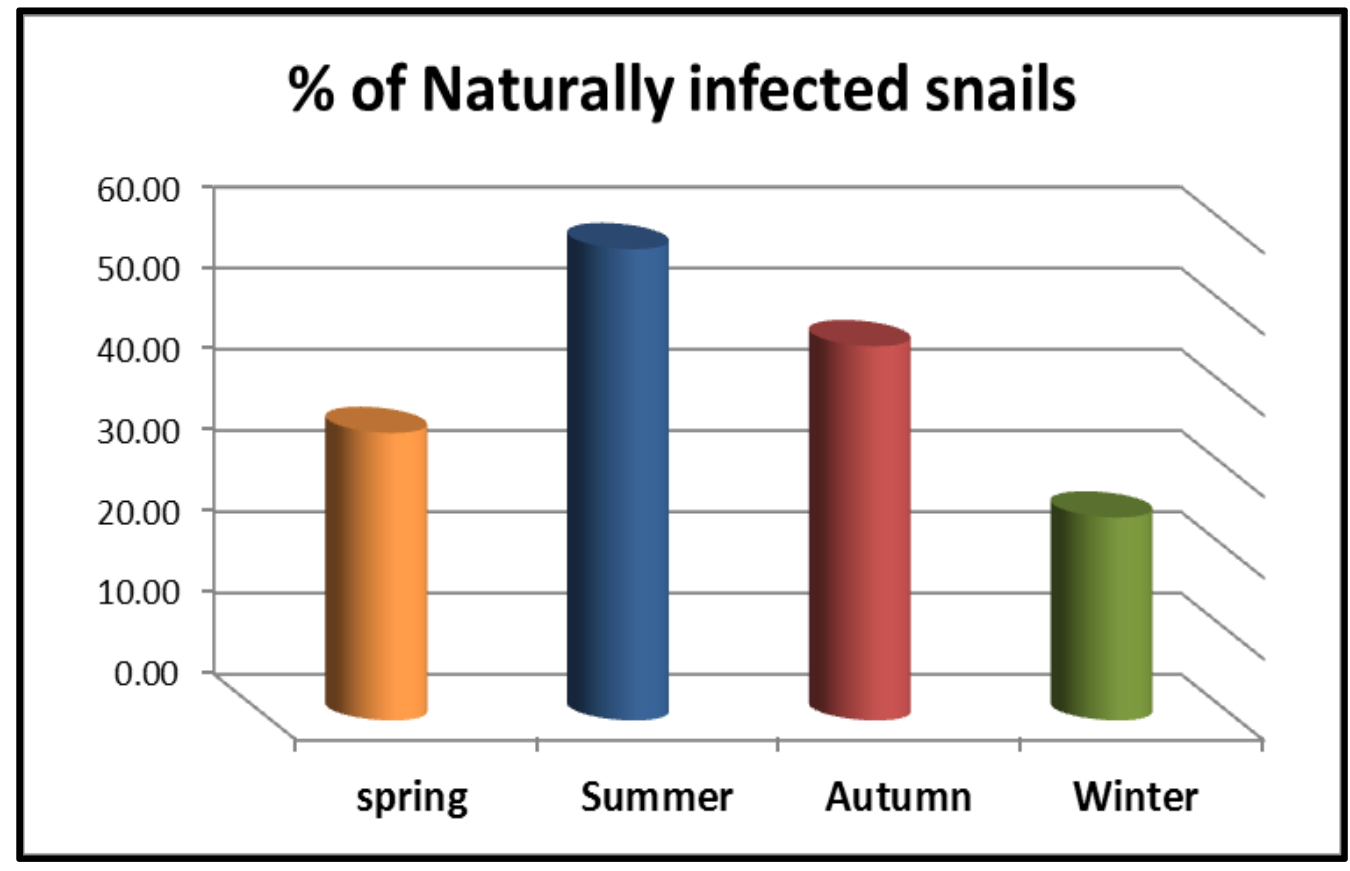

Fig(2): Percentage of naturally infected snails in the examined watercourses during the four seasons ( spring,2018 to winter,2019) at AlFayoum Governorate 
From the previous data, the total number of collected snails is 8799 snail/ year (Table 2 and Fig 1), the highest snails density was recorded in spring season (4808 snails).Out of the total number of snails collected

/year , 3694 snails were found infected with trematodes cercariae, the highest infection rate was recorded during summer season (1642 snails).

Regarding the distribution of snails among the selected water courses,

Bahr dissia, Hawaret el-makta and Taton were contain high snails density among the selected watercourses recording 3046, 2729 and 1001 snails / year, however in distribution of naturally infection snails, Hawaret el-makta recorded the highest infection rate during four season.

\section{Discussion}

Many species of fresh water snails are intermediate hosts of trematode parasites, which pose serious risks to human and livestock and can adversely affect both agricultural practices and the economy.Water resources development schemes, particularly irrigation ones, can contribute to the introduction and spread of the snail intermediate hosts of parasitic trematodesand facilitate human contact with parasitic risk foci [6]. Therefore, the present study was concerned with snail survey in different water courses at Al-Fayoum Governorate for detecting their infection with trematode parasites during four seasons (spring,2018 to winter,2019).

From the present study, it was generally observed that population density of fresh water snails are variable in various habitats and seasons. Thus, the highest number of collected snails during the study period was recorded during spring ,2018 while the lowest one was during winter,2019 . This may be correlated with the recorded water temperature during the study period, as the mean water temperature during spring was 22.9c and was $14.4 \mathrm{c}$ during winter .This finding is in agreement with that of ElEmamand Roushd

[7] who recorded that the optimum water temperature for the snail intermediate hosts of schistosomaisis was between 22-26c - However, Kariuki [8] did not find a significant link between snail abundance and water temperature.

The pattern of snail intermediate hosts distribution in watercourses and the prevalence of their infection with trematodes are among the measurable indicators that reflect the magnitude of transmission [9]. Kishk

[10] studied the status of distribution of snail vectors of schistosomiasis and the transmission of the disease in Al-Fayoum governorate and concluded that prevalence of schistosomiasis was substantially high in the hamlets $(20-30 \%)$ compared to $2-3 \%$ in the main village. Such a highly infected community represents a continuous pool of reinfection of the waterways, an issue that needs to be further examined to determine its relation to the hamlets' specific ecosystem characteristics.

In the present study, status of the snail intermediate hosts of schistosomiasis distribution was recorded in many hamlets in Al-Fayoum Centers during 2018-2019. Results showed that B. alexandrina snails, the vector of Schistosoma mansoni, were highly distributed in all types of examined watercourses selected (canals and drains) with infestation percentage of $91.77 \%$ ( 
8075 snails collected out of 8799 snails).

Natural infection of $B$. alexandrina with $S$. mansoni was observed inall selected watercourses with infection rate (44.69\%). Meanwhile, $B$. truncatus snails were observed in all watercourses with infestation percentage of $1.81 \%$ and 159 collected snails/8799 snails. Naturally infected

B. truncatus with $S$. haematobium was observed only in Senours, Bahr dissia, Hawaret el-maktaa, Kasr Elbanat and Taton watercourses with infection rate $21.38 \%$. The present natural infection percentage, among B. alexandrina and

B. truncatus, were relatively higher than those in previous studies.

For more exploration, Habib [11] studied the effect of geographical distribution of $B$. alexandrina snails on their susceptibility to Schistosoma mansoni infection in some localities in Egypt and found very low natural $S$. mansoni infection, $0.38 \%$, among thecollected snails. Also, [12] revealed that natural snails infection can occur in Nile especially in sites where fishing and agricultural activities, but mostly by low ratio for $B$. alexandrina and $B$. truncatus snails $0.71 \%$ and 0.29 , respectively.

On the other hand, the strategic plan designed by the researches may perhaps affectthe results of certain study. The study of Aboelhadid [13] in Al Fayoum may verify this issue. The authors studied digenetic larval stages in relevant snails, applying a PCR molecular system to diagnose trematodal infection after being negative by the usual microscopic method. The authors recoded $14.84 \%$ infection rate among the examined B. alexandrina.

The records of previous authors more or less matches with that recognized by
Wanas

[14] and Aboelhadid [15]as well, in which $10.50 \%$ and $5.50 \%$ infection rates among snails`collected from Giza and BeniSuef districts respectively.

The present survey recorded some other types of snails next to B. alexandrina \& B. truncatus snails, e.g. Physa acuta, Lymnaea natalensis, Cleopatra bulimoides and Melanoides tuberculata. The highest association percentage of each of $B$. alexandrinaand $B$. truncatus were with Physa acuta followed by L. natalensis. In the meantime, both snails Pila ovata and Bellamya unicolor showed the lowest association with $B$. alexandrina and $B$. truncates.

Previous studies recorded the association between $B$. alexandrina and

$B$. truncatus snails with other snail species. Yousef [16] found that $B$. alexandrina snails were positively associated with $L$. carinatus and $C$. bulimoides while $B$. truncatus snails were found to be positively associated with Physa acuta snails. Also, Abdel Kader [17] and Abdel Kader [18] reported that $B$. alexandrina snails mostly existed with L. carinatus and Physa acuta snails. However Frandsen [19], Frandsen \& Christensen [20], Madsen \& Frandsen [21] and Madsen [22] found that the presence of Helisoma duryi caused an important reduction in the growth of infected Biomphalaria pfeifferi, B. glabrata, $B$. camerunensis and $B$. alexandrinawhen being in a direct competition situation.

\section{CONCLUSION}

The present study aimed to reveal initially vital issues related to the current status of medically important snails, the essential hosts in the life cycle of parasitic 
trematodes. The current study revealed that Fayoum water canals harbour many fresh water snails, some of them were found infected with cercariae of trematodes of medically importance. Snails are possibly

affected by unsettled and disturbed ecosystem which needs repeated investigations considering the variable influencing factors.

\section{References}

[1] Loker ES, Moyo HG, Gardner SL.(1981):Trematode- gastropod associations innine non- lacustrine habitats in Mwanza region of Tanzania.Parasitol.1981;83:381-99.

[2] World Health Organization (1995): Control of foodborne trematode infections. Report of a WHO Study Group. Geneva, (WHO Technical Report Series, No. 849).

[3] Ahmed A Abo-Madyan 1, Tosson A Morsy, Saad M Motawea, Manal F El Garhy, Ahmed M A Massoud (2005): Spot light survey on fresh-water snails of medical importance in Al Fayoum Governorate, Egypt, $J$ Egypt Soc Parasitol;35(1):49-58.

[4] Yousif, F.; Ibrahim, A.; Abd El-Kader, A. and El-Bardicy, S. (1998): Invasion of the Nile Valley by a Hybrid of Biomphalaria glabrata and Biomphalaria alexandarina, snail vectors of Schistosoma mansoni in Egypt. J. Egypt. Soc. Parasitol., 28: 569-582.

[5] Favre, T.C.; Bgea , T.H.P.; Rotenberg, L.; Silva, H.S. and Pieri, O.S. (1995): Cercarial emergence of schistosoma mansoni from Biomphalaria glabrata and
Biomphalaria straminea. Mem. Inst. Oswaldo Cruz, 90: 565- 567.

[6] Steinmann, P.; Keiser, J.; Bos, R.; Tanner, M. and Utzinger, J. (2006) Schistosomiasis and water resources development: systematic review, metaanalysis, andestimates of people at risk. Lancet Infect Dis 6: 411-425.

[7] El-Emam, M.A. and Roushdy, M.Z. (1981 ): Ecological studies on snail intermediate hosts of Schistosomes in certain areas in Egypt .EgyptJ. Bilh., 8: 75-86.

[8] Kariuki, H.C.; Clennon, J.A.; Brady, M.S.; Kitron, U.; Sturrock, R.F.; Ouma, J.H.; Ndzovu,S.T.M.; Mungai, P.;Hoffman, O.; Hamburger, J.; Pellegrini, C.; Muchiri, E.M.and King,C.H. (2004) :Distribution patterns and cercarial shedding of Bulinus nasutus and other snail species in the Msambweni area, Coast Province, Kenya. Am. J.

Trop.Med. Hyg. 70, 449-456

[9] Sayed, H.A.; El-Ayyat, A.; Abdel Kader, A.; Sabry, H. and Amer, N.A. (2004):Epidemiology of Schistosoma mansoni infection and its relationship to snail distribution in a village at the Nile bank south to Cairo. J. Egypt. Pub. Hlth. Assoc., 79: 95-117. 
[10] Kishk, F. M., Gaber, H. M., \& Abd-Allah, S. M. (2004). Towards enhancing community health in ElFayoum, Egypt, using ecosystem approaches. EcoHealth, 1(2), SU84-SU96.

[11] Habib, M.R. (2010): Studies on the Effect of geographical distribution of B. alexandrina snails on theire susceptibility to schistosoma mansoni infection in some localities in Egypt Cairo. Ms.D. Thesis. Invertebrates and Parasitology, Menoufiya Univ., Egypt

[12] EL-Hommossany, K.M. A. (2006):Schistosomiasis transmission in The River Nile at Greater Cairo. Ph.D. Thesis. Environmantal Sciences, Inst. Of Studies Environmental and Researches Environmental, Ain Shams Univ., Egypt.

[13] Aboelhadid, S. M., Thabet, M., El-Basel, D., \& Taha, R. (2016). Digenetic larvae in Schistosome snails from El Fayoum, Egypt with detection of Schistosoma mansoni in

$\begin{array}{ll}\text { the } & \text { snail } \\ \text { by } & \text { PCR. Journal of }\end{array}$

Parasitic Diseases, 40(3), 730-734.

[14] Wanas MQA, Abou-Senna FM, Al-Shareef AMF. (1993):Studies on larval digenetic trematodes of Xiphidiocercaria from some Egyptian freshwater snails. J Egypt Soc Parasitol. 1993;23:829-851. [PubMed] [Google Scholar]

[15] Aboelhadid, SM (2004): Biological studies on parasites transmitted from some freshwater snails to other hosts. Ph.D. Thesis, Faculty of Veterinary Medicine, Beni-

\section{Suef, Cairo University}

[16] Yousif, F.; Ibrahim, A.; Abd ElKader, A. and El-Bardicy, S. (1998a) Invasion of the Nile Valley by a Hybrid of Biomphalaria glabrata and Biomphalaria alexandarina, snail vectors of Schistosoma mansoni in Egypt.

$$
\text { J. Egypt. Soc. Parasitol., 28: } 569 \text { - }
$$
582.

[17] Abdel kader, A. (2001): Effect of ecological parameters on the distribution of snail vectors of schistosomiasis.J.Egypt. Soc. Parasite., 31:145-152.

[18] Abdel-Kader, A.E. and Sharaf El-Din, A.T. (2005) :Effect of the pesticides carbofuran (carbamate) and profenophos (organophosphorus) on Biomphalaria alexandrina and on its infection with Schistosoma mansoni miracidia. Egypt,J. Schist. Inf. End. Dis., 27: 71-83.

[19] Frandsen, F. (1976) :The suppression, by Helisoma duryi, of the cercarial production of Schistosoma mansoni-infected Biomphalaria pfeifferi. Bulletin of the World Health Organization, 53: 385-390.

[20] Frandsen, F. \& Christensen, N.O. (1977): Effect of Helisoma duryi on the survival, growth, and cercarial production of Schistosoma mansoni infected Biomphalaria glabrata. Bulletin of the World Health Organization, 55: 577-580. 
ISSN: 2536-9482 (Online) Fayoum University Medical Journal Abd El-Hafeez et al., 2018,8(3), 61-70

[21] Madsen, H. \& Frandsen, F. (1979):Studies on the interspecific competition between Helisoma duryi

[22] Hydrobiologia, 66: 17-23

[23] Madsen, H. (1985):The effect of Helisoma duryi on the cercarial production of [24] nd direct competition. Zeitschrift fur Parasitenkunde, 71: 71-77.
(Wetherby) and Biomphalaria camerunensis (Boettger). Size-weight relationships and laboratory competition experiments. Schistosoma mansoni infected Biomphalaria alexandrina: evaluation of chemical interferences 